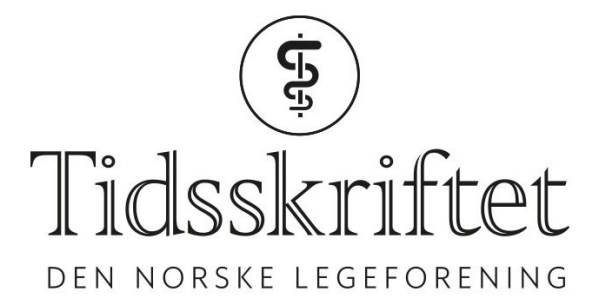

\title{
Sexarbeideres helse blir fortsatt ignorert
}

LEDER

KETIL SLAGSTAD

E-post: ketil.slagstad@medisin.uio.no

Ketil Slagstad er ph.d.-stipendiat i medisinsk historie ved Institutt for helse og samfunn, Universitetet i Oslo.

Forfatteren har fylt ut ICMJE-skjemaet og oppgir ingen interessekonflikter.

Kriminalisering av prostitusjon forverrer livssituasjonen til dem som selger sex og øker risikoen for hivsmitte.

1. desember markeres Verdens aidsdag. Over hele verden fortsetter hiv-aids-epidemien å ramme utsatte grupper i samfunnet og forsterke stigmatisering og diskriminering av disse (1). Blant disse er sexarbeidere - en gruppe som tidlig ble gjort til syndebukker for epidemien $(2,3)$, men som ikke har blitt lyttet til når samfunnet har vedtatt lover som berører dem.

Sexarbeidere over hele verden - fra lav- til høyinnteksland - er betydelig utsatt for hivsmitte (4). Drøyt $10 \%$ av alle kvinnelige sexarbeidere er hivpositive, men med store regionale forskjeller (4). Tilgangen til effektiv hivbehandling er begrenset, og de som injiserer rusmidler, er ekstra utsatt for smitte, blant annet som følge av mangel på rent brukerutstyr (4).

En viktig grunn til at sexarbeidere er mer utsatt for hivsmitte, er kriminalisering av prostitusjon. Dette kan ha en rekke konsekvenser (4-6): Salg av sex flyttes over på mindre trygge arenaer av frykt for å bli arrestert, enten det er sexarbeideren eller kunden. Kriminelle forhold, som vold, blir ikke anmeldt (7). Når besittelse av kondomer blir brukt som bevismateriale, leder dette til mindre bruk av kondom $(5,7)$. Sexarbeideren forhindres fra å organisere seg, selv om det å arbeide sammen kan gjøre det lettere å beskytte seg mot seksuelt overførbare infeksjoner, redusere vold og øke sosial støtte (5).

Menneskehandel og sexarbeid blir ofte blandet sammen, fordi menneskehandel også forekommer i prostitusjonen. Denne sammenblandingen kan gjøre det vanskeligere å identifisere og gjøre noe med skadelige arbeidsforhold for sexarbeidere. Den kan også vanskeliggjøre hivforebyggende arbeid $(8,9)$. Debatten om kriminalisering ender ofte i en ideologisk diskusjon om sexarbeidets natur, som skygger for faktiske arbeidsforhold og konsekvenser av kriminalisering, ikke minst helsemessige (10). Sexarbeidere er ingen ensartet gruppe, men består av personer av alle kjønn, inkludert transpersoner (9). Utfordringene og behovene er ulike, og derfor må sexarbeiderne selv og deres organisasjoner trekkes med i utarbeiding av politikk, lovverk og helsetjenester. 
En viktig grunn til at sexarbeidere er mer utsatt for hivsmitte, er kriminalisering av prostitusjon

Men sexarbeidere blir sjelden lyttet til (11). Da jeg nylig var på en konferanse om europeisk hivpolitikk, sa en sexarbeideraktivist i en paneldiskusjon at deres organisasjoner ikke hadde blitt konsultert i arbeidet med å innføre preeksponeringsprofylakse mot hiv (dvs. hivmedisiner tatt forebyggende) blant sexarbeidere. Han fortalte at bruk av kondom for mange sexarbeidere ikke bare handler om å beskytte seg mot infeksjoner, men representerer en barriere som beskytter selvet, en mulighet for å kunne skille sex med kunder fra sex med partnere, og at profylaksen kunne føre til press om å droppe kondomet. Preeksponeringsprofylakse kan være et viktig hivforebyggende tiltak, men poenget er tiltaket må tilpasses sexarbeidernes behov for at det skal lykkes.

Det er behov for en stortingsmelding om prostitusjon som tar de komplekse sosiale problemene og utfordringene på alvor (12). Da hivepidemien kom til Norge i 1980-årene valgte norske myndigheter å spille på lag med sexarbeiderne (13). Helsedirektoratet ansatte sexarbeidere for å drive helsefremmende og forebyggende arbeid. Den gang var fokuset på helsemessige og sosiale tiltak. I dag har dette blitt erstattet med en juridisk linje med kriminalisering av kunden, ofte markedsført som «den nordiske modellen», som har blitt kraftig kritisert av Amnesty International (7). Skiftet kommer til syne ved at helsemessige konsekvenser av sexkjøpsloven er fraværende i den offentlige debatten, inkludert i en evaluering bestilt av regjeringen, der hivinfeksjon ikke nevnes med ett ord (14).

\section{LITTERATUR:}

1. UNAIDS. Fact Sheet - Global AIDS Update 2019.

https://www.unaids.org/sites/default/files/media_asset/UNAIDS_FactSheet_en.pdf Lest 24.10.2019.

2. Skilbrei M-L. The Development of Norwegian Prostitution Policies: A Marriage of Convenience Between Pragmatism and Principles. Sex Res Soc Policy 2012; 9: 244-57. [CrossRef]

3. Middelthon AL. De farlige andre: om anti-struktur og metaforiserings- og metonymiseringsprosesser i hiv-epidemien. Oslo: Universitetet i Oslo, 1992.

4. Shannon K, Crago AL, Baral SD et al. The global response and unmet actions for HIV and sex workers. Lancet 2018; 392: 698-710. [PubMed][CrossRef]

5. Shannon K, Strathdee SA, Goldenberg SM et al. Global epidemiology of HIV among female sex workers: influence of structural determinants. Lancet 2015;385: 55-71. [PubMed][CrossRef]

6. Reeves A, Steele S, Stuckler D et al. National sex work policy and HIV prevalence among sex workers: an ecological regression analysis of 27 European countries. Lancet HIV 2017; 4: e134-40.

[PubMed][CrossRef]

7. Amnesty International. The Human Cost of "Crushing” the Market: Criminalization of Sex Work in Norway.

https://www.nswp.org/sites/nswp.org/files/Norway\%2oExecutive\%20Summary\%2C\%20Amnesty\%2oInte rnational\%20-\%202016.PDF Lest 28.10.2019.

8. Steen R, Jana S, Reza-Paul S et al. Trafficking, sex work, and HIV: efforts to resolve conflicts. Lancet 2015;385: 94-6. [PubMed][CrossRef]

9. Strathdee SA, Crago A-L, Butler J et al. Dispelling myths about sex workers and HIV. Lancet 2015; 385: 4-7. [PubMed][CrossRef]

10. Wolffers I, van Beelen N. Public health and the human rights of sex workers. Lancet 2003; 361: 1981. [PubMed][CrossRef]

11. Majic S. Serving Sex Workers and Promoting Democratic Engagement: Rethinking Nonprofits' Role in American Civic and Political Life. Perspect Polit 2011; 9: 821-39. [CrossRef]

12. Pro senteret. Året 2018 - En oppsummering av aktivitetene ved Pro Sentret.

http://prosentret.no/wp-content/uploads/2019/03/\%C3\%85rsrapport-2018.pdf Lest 28.10.2019. 
13. Slagstad K, Lie AK. Selling Sex in the Age of AIDS: Activism, Politics, and Medicine in Norway, 1983-1990. I: Weston J, Kershaw H, red. Histories of HIV/AIDS in Europe, 1980-2019. Manchester: Manchester University Press; akseptert for publisering.

14. Rasmussen I, Strøm S, Sverdrup S et al. Evaluering av forbudet mot kjøp av seksuelle tjenester. Rapport nr. 30/2014.

https://www.vista-analyse.no/no/publikasjoner/evaluering-av-forbudet-mot-kjop-av-seksuelle-tjeneste r/ Lest 28.10.2019.

Publisert: 18. november 2019. Tidsskr Nor Legeforen. DOI: 10.4045/tidsskr.19.0691

(C) Tidsskrift for Den norske legeforening 2020. Lastet ned fra tidsskriftet.no 